\title{
Contribution of mutations in ATM to breast cancer development in the Czech population
}

\author{
JANA SOUKUPOVA $^{1}$, PAVEL DUNDR ${ }^{2}$, ZDENEK KLEIBL $^{1}$ and PETR POHLREICH ${ }^{1}$ \\ ${ }^{1}$ Department of Biochemistry and Experimental Oncology, First Faculty of Medicine; ${ }^{2}$ Institute of Pathology, \\ First Faculty of Medicine and General Teaching Hospital, Charles University, Prague, Czech Republic
}

Received December 12, 2007; Accepted January 21, 2008

\begin{abstract}
Mutations in the ATM gene are the cause of a rare autosomal recessive syndrome, ataxia-telangiectasia (AT). Of the general population, $\sim 0.35-1 \%$ has been estimated to be heterozygous for a germline mutation in the ATM gene. The finding that $A T M$ heterozygotes have an increased breast cancer risk was supported by some studies but not confirmed by others. In our study, the entire coding sequence of the ATM gene was prescreened for mutations by the protein truncation test to detect the chain-terminating mutations that are highly predominant in patients with AT. DNA sequencing then characterized 3 (1.9\%) pathogenic mutations among 161 high-risk breast cancer patients. The c. $.5177+1 \mathrm{G}>\mathrm{A}$ splicing mutation was a novel gene alteration. No mutation was detected in a group of 183 control individuals. Our results suggest that truncating mutations in $A T M$ increase breast cancer risk and contribute to inherited breast cancer. The analysis further uncovered the c.1066-6T $>\mathrm{G}$ splicing mutation once among high-risk patients $(0.6 \%)$ and twice among controls $(1.1 \%)$ suggesting that this mutation does not confer an increase in breast cancer risk. On the other hand, individuals heterozygous for this truncating variant displayed loss of exon 11 in 50\% of ATM transcripts. Immunohistochemistry did not detect the ATM protein in the tumor sample carrying this mutation. Thus, the association of the c.1066-6T $>\mathrm{G}$ mutation with familial breast cancer remains uncertain. Loss of the wild-type ATM allele has not been detected in the tumor samples from heterozygous carriers of the ATM mutation. Our experiments did not detect the hypermethylation of the ATM promoter in any of the DNA samples from tumor tissues.
\end{abstract}

\section{Introduction}

It has been estimated that hereditary predisposition accounts for $5-10 \%$ of breast cancer cases. Germline mutations in the

Correspondence to: Dr Jana Soukupova, Department of Biochemistry and Experimental Oncology, First Faculty of Medicine, Charles University, U Nemocnice 5, 12853 Prague, Czech Republic E-mail: jproko@lf1.cuni.cz

Key words: ATM gene, ataxia-telangiectasia, breast cancer susceptibility genes, protein truncation test two major susceptibility genes, BRCAl and -2 , were identified in $60-80 \%$ of women with hereditary breast cancer (1). Besides $B R C A 1 / 2$, mutations in genes with lower penetrance, such as the ataxia-telangiectasia-mutated gene (ATM and MIM 607585 ), may explain much of the hereditary predisposition to breast cancer.

ATM is a protein kinase that has a key role in a signalling cascade responding to DNA double-strand breaks and is essential in coordinating the cellular response as reviewed recently (2). The substrates include proteins such as p53, $\mathrm{Mdm} 2$ and cAbl that influence the G1 checkpoint; NbsS1, $\operatorname{Rad} 51$, BRCA1 and FANCD2 which are involved in the transient ionizing-radiation-induced $\mathrm{S}$-phase arrest and BRCA 1 and Chk $1 / 2$ involved in the G2 checkpoint (3). Phosphorylation of these proteins, in turn, leads to the two crucial responses to DNA damage of the activation of the cell-cycle checkpoints and initiation of the DNA repair.

Biallelic mutations in the ATM gene cause the rare autosomal recessive disorder, ataxia-telangiectasia (AT), that has the incidence of 1/40 000-1/300 000 live births in various ethnic groups (4). The disease is characterized, among others, by hypersensitivity to ionizing radiation and a predisposition to cancer (5). At least $70 \%$ of ATM mutations identified in AT result in the premature termination of translation (see http://www.vmresearch.org/atm.htm). AT heterozygotes that represent $0.35-1 \%$ of the general population are clinically asymptomatic. However, numerous epidemiological studies have noted a significantly elevated frequency of female breast cancers among AT relatives $(6,7)$. Nevertheless, subsequent analyses have not demonstrated a higher number of ATcausing mutations either in individuals with an early onset of breast cancer or in hyperradiosensitive breast cancer patients compared with the controls $(8,9)$. On the other hand, it has been suggested that a number of missense variants, mostly unrelated to AT, may play a role in breast cancer predisposition (10). The recent studies of Renwick et al, performed in highrisk breast cancer families, identified $A T M$-truncating mutations causing AT as breast cancer susceptibility alleles. The relative risk of breast cancer associated with ATM mutations was estimated to be 2.37 (11).

To determine the role of the mutations occurring in AT heterozygotes in breast cancer development in the Czech population, we screened the entire coding sequence of the ATM gene for truncating mutations in families with a history of breast cancer and in high-risk patients not selected on the 
basis of their family history of cancer. All of the patients were prescreened for mutations in the BRCAl/2 genes, and cases of breast cancer related to these genes were excluded from ATM testing (12). To estimate the frequency of the mutations in the general population, an analysis was also performed in a group of healthy individuals.

\section{Materials and methods}

Patient samples. EDTA blood samples were collected from high-risk breast cancer patients at the Department of Oncology and at the Department of Gynecology and Obstetrics of the First Faculty of Medicine of Charles University in Prague. A total of 114 patients were selected from families with two cases of breast cancer diagnosed before the age of 50 , or three or more cases of breast (or ovarian) cancer diagnosed at any age. Genetic testing was further offered to patients diagnosed with breast cancer before the age of 40 (42 women) or with bilateral breast cancer before the age of 50 (5 women), regardless of the family history of cancer. The paraffin-embedded tumor samples from ATM mutation carriers were obtained from the Institute of Pathology of the First Faculty of Medicine. The control blood samples were obtained from random blood donors of mixed gender. All women in the study gave signed informed consent prior to the genetic testing. The protocol of investigation was approved by the ethics committee at the First Faculty of Medicine.

Total RNA was purified from peripheral blood lymphocytes by an acid guanidinium thiocyanate-phenol-chloroform extraction (13) and reverse-transcribed into cDNA using random hexamer primers according to the manufacturer's protocol (Roche). Genomic DNA was isolated from the blood samples using the Wizard Genomic DNA purification kit (Promega) and from tumor samples using the QIAamp DNA mini kit (Qiagen).

Mutation analysis. Mutational screening, based on an RNAanalysis, included amplification of the entire coding sequence of the ATM gene, pre-screening of mutations by the protein truncation test (PTT) and their characterization by direct DNA sequencing. The coding region of ATM was divided into seven overlapping fragments and amplified from cDNA by the polymerase chain reaction (PCR). Amplifications were performed in $10 \mu 1$ reaction mixtures containing $1 \mu 1$ of PCR buffer (Roche Molecular Biochemicals), $0.2 \mathrm{mM}$ of each $\mathrm{dNTP}, 0.4 \mu \mathrm{M}$ of each primer, $1 \mu \mathrm{l}$ of cDNA template and $0.5 \mathrm{U}$ of Fast Start Taq DNA polymerase (Roche). Following the initial denaturation (at $95^{\circ} \mathrm{C}$ for $6 \mathrm{~min}$ ), 35 cycles (at $95^{\circ} \mathrm{C}$ for $30 \mathrm{sec}, 58$ or $62^{\circ} \mathrm{C}$ for $30 \mathrm{sec}$ for individual fragments and $72^{\circ} \mathrm{C}$ for $2 \mathrm{~min}$ ) and a final extension (at $72^{\circ} \mathrm{C}$ for $7 \mathrm{~min}$ ) were performed. PCR products were analyzed on $1.5 \%$ ethidium bromide-stained gels. Primer sequences were based on Telatar et al (14). From each sample, $1 \mu 1$ of the PCR product was incubated in the TnT/T7 coupled transcription/translation system (Promega) supplemented with $\left[{ }^{35} \mathrm{~S}\right]$ methionine (Amersham Biosciences) following the manufacturer's protocol and the translated proteins were then separated on $12 \%$ SDSpolyacrylamide gels. After electrophoresis, gels were fixed, washed in fluorographic solution (Amplify, Amersham Biosciences), dried and exposed to X-ray film at $-80^{\circ} \mathrm{C}$. PCR products that gave rise to truncated proteins by PTT analysis were purified and directly sequenced using the BigDye terminator cycle sequencing kit version 3.1 in a model ABI PRISM 310 or 3130 automated DNA sequencer (Applied Biosystems). Mutations were confirmed by a nucleotide sequence analysis of the DNA samples.

The nomenclature of the mutations used is according to den Dunnen and Paalman (15), with the nucleotides being numbered from the A of the ATG initiation codon of the GenBank reference sequence U33841 for the complete ATM cDNA. The original designations for the ATM mutations commonly referred to in the literature are included for ease of cross-referencing.

Analysis of splicing products. To specify precisely the effect of the mutations, IVS10-6T >G, IVS36+1A > G and c.60969delTTCTT on splicing, we analyzed RNA samples extracted from the peripheral blood of heterozygous mutation carriers and control healthy individuals. Individual cDNA samples obtained by reverse transcription served as templates for PCR-amplification using the primers flanking either exon 11 (5'-GATCTGCTAGTGAATGAGATAAGTC-3' - forward and 5'-AATGCAACTTCCGTAAGGC-3' - reverse) or exon 36 (5'-CCATTGACAAGACTTGAAGGACT-3' - forward and 5'-GCTGTAGATAGGCCAGCATTG-3' - reverse) or exon 44 (5'-CAGAAGTATAGGGGAGCCAGATAG-3' - forward and 5'-CTGACGGAAGTGCAATGGT-3' - reverse). PCR reactions were performed in 27 cycles (annealing at 60,58 and $64^{\circ} \mathrm{C}$, respectively) while other reaction conditions and cycling parameters were as described above. The forward primers were fluorescently labeled with 6-FAM. The PCR products were separated in an ABI 3130 automated DNA sequencer and relative quantities of the full-length products and the products lacking the respective exon were determined by GeneMapper software version 4.0 (Applied Biosystems).

Immunohistochemistry. Paraffin sections obtained from the tumor tissue or metastasis of heterozygous mutation carriers were used for histological and immunohistochemical examination. The mouse monoclonal antibody ATM Ab-8 (clone ATX08) (Neomarkers, Lab Vision Corporation) specific to the C-terminus of ATM was used for the detection of the protein according to the manufacturer's instructions.

LOH analysis. Paired samples of lymphocyte and tumor DNA served for LOH analysis which was carried out for three microsatellite markers: one (D11S2179) intragenic to ATM and two (D11S1819 and D11S1294) that flank this gene on the centromeric and telomeric side, respectively. Primer sequences for microsatellite marker loci were retrieved from the genome database (http://www.gdb.org). PCR reactions of a $10 \mu 1$ volume contained $0.5 \mathrm{U}$ of Taq DNA polymerase (Finnzymes) and 20-50 ng of DNA. Amplification was carried out under the following conditions: denaturation at $93^{\circ} \mathrm{C}$ for $3 \mathrm{~min}$; 35 cycles of $93^{\circ} \mathrm{C}$ for $30 \mathrm{sec}, 55,60$ or $65^{\circ} \mathrm{C}$ (for D11S1294, D11S1819 and D11S2179, respectively) for $30 \mathrm{sec}$ and $72^{\circ} \mathrm{C}$ for $30 \mathrm{sec}$ with a final extension at $72^{\circ} \mathrm{C}$ for $5 \mathrm{~min}$. PCR products were run on precast Spreadex gels using SEA 2000 electrophoretic apparatus (Elchrom Scientific) and visualized by SYBR-Gold nucleic acid gel staining (Invitrogen) 
Table I. The frequencies of the ATM mutations in relation to the classification of patients.

\begin{tabular}{|c|c|c|c|}
\hline Classification & $\begin{array}{l}\text { No. of } \\
\text { patients/controls }\end{array}$ & $\begin{array}{c}\text { No. of mutations exluding } \\
\text { c. } 1066-6 \mathrm{~T}>\mathrm{G}(\%)\end{array}$ & $\begin{array}{c}\text { c. } 1066-6 \mathrm{~T}>\mathrm{G} \\
(\%)\end{array}$ \\
\hline \multicolumn{4}{|l|}{ Breast cancer patients } \\
\hline from $\mathrm{HBC} / \mathrm{HBOC}$ families & 114 & $2(1.8)$ & $1(0.9)$ \\
\hline \multicolumn{4}{|c|}{ Without family history of breast cancer } \\
\hline Bilateral breast cancer before 50 & 5 & $0(0)$ & 0 \\
\hline Breast cancer before 40 & 42 & $1(2.4)$ & 0 \\
\hline Total & 161 & $3(1.9)$ & $1(0.6)$ \\
\hline Controls & 183 & 0 & $2(1.1)$ \\
\hline
\end{tabular}

HBC, hereditary breast cancer and $\mathrm{HBOC}$, hereditary breast and ovarian cancer.

Table II. The ATM mutations identified in high-risk breast cancer patients.

\begin{tabular}{|c|c|c|c|c|}
\hline Family no. & Mutation $^{\mathrm{a}}$ & Predicted effect & Diagnosis (age) & $\begin{array}{l}\text { Cancers in family } \\
\text { (age at onset) }\end{array}$ \\
\hline 410 & c. $5177+1 \mathrm{G}>\mathrm{A}$ & $\begin{array}{l}\text { Exon } 36 \text { skipped, } \\
\text { ter } 1680\end{array}$ & Bilateral breast cancer $(42,44)$ & $\begin{array}{l}\text { Pancreatic ( } 75) \text {, } \\
\text { breast (64), breast (?) }\end{array}$ \\
\hline 116 & c. $5932 \mathrm{G}>\mathrm{T}$ & E1978X & $\begin{array}{l}\text { Bilateral breast }(53,60) \text { and } \\
\text { ovarian cancer }(61)\end{array}$ & $\begin{array}{l}\text { Ovarian (57), leukemia (?) } \\
\text { kidney (?), lung (59) }\end{array}$ \\
\hline 96 & c.6096-9delTTCTT & $\begin{array}{l}\text { Exon } 44 \text { skipped, } \\
\quad \text { ter } 2032\end{array}$ & Breast cancer (37) & Pancreatic (73) \\
\hline 69 & c. $1066-6 \mathrm{~T}>\mathrm{G}$ & $\begin{array}{l}\text { Exon } 11 \text { skipped, } \\
\text { ter } 372\end{array}$ & Breast cancer (32) & Breast (60), breast (?) \\
\hline
\end{tabular}

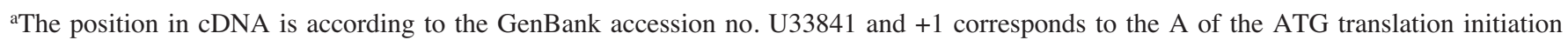
codon.

according to the manufacturer's instructions. The ElQuant software (Elchrom Scientific) was used to choose an appropriate gel and for electrophoretic conditions. Two-fold or greater reduction in the relative allele intensity ratio measured between the tumor and normal DNA was indicative of LOH for a given marker. The assessment of allele loss was accomplished by two independent observers and for the cases described herein was visually obvious.

Promoter methylation analysis. The DNA isolated from the tumor tissue was analyzed for the cytosin methylation status of the ATM promoter by bisulfite sequencing. DNA samples $(0.5 \mu \mathrm{g}$ of each) were modified by bisulfite using the EZ DNA Methylation-Gold kit (Zymo Research) following the manufacturer's protocol. CpGenome Universal Methylated DNA (Intergen) was used as a positive control. The PCR mixture contained $1 \mathrm{X}$ PCR gold buffer, $2 \mathrm{mM} \mathrm{MgCl}, 0.4 \mathrm{mM}$ of each dNTP, $0.4 \mu \mathrm{M}$ of each primer (5'-TTTTTAGATTT GGAGGGG-3' - forward and 5'-CCCACTTCTAAAAAAA AAAA-3' - reverse), $2 \mu 1$ of bisulfite-modified DNA and $0.625 \mathrm{U}$ of hot-start AmpliTaq gold polymerase (Applied
Biosystems) in a total volume of $25 \mu 1$. Amplification was performed under the following conditions: $95^{\circ} \mathrm{C}$ for $10 \mathrm{~min}$ and 40 cycles of $95^{\circ} \mathrm{C}$ for $30 \mathrm{sec}, 52^{\circ} \mathrm{C}$ for $30 \mathrm{sec}$ and $72^{\circ} \mathrm{C}$ for $40 \mathrm{sec}$. The PCR products were directly sequenced using the forward primer and the BigDye terminator cycle sequencing kit version 3.1 in a model ABI PRISM 3130 automated DNA sequencer (Applied Biosystems).

\section{Results}

We screened 161 high-risk breast cancer patients and 183 controls for truncating ATM mutations that predominate in AT. Within the analyzed individuals, $4(2.8 \%)$ carried distinct alterations that include a nonsense mutation and 3 splicing variants resulting in a shift of the ATM reading frame and the premature termination of translation (Tables I and II). The c.5932G $>$ T nonsense mutation that leads to the termination of translation at codon 1978 has previously been shown as a causative in AT (16). The c.5177+1G $>$ A (IVS36+1G>A) mutation affects the 5' splice site, which results in the aberrant splicing and loss of exon 36 . It is likely 


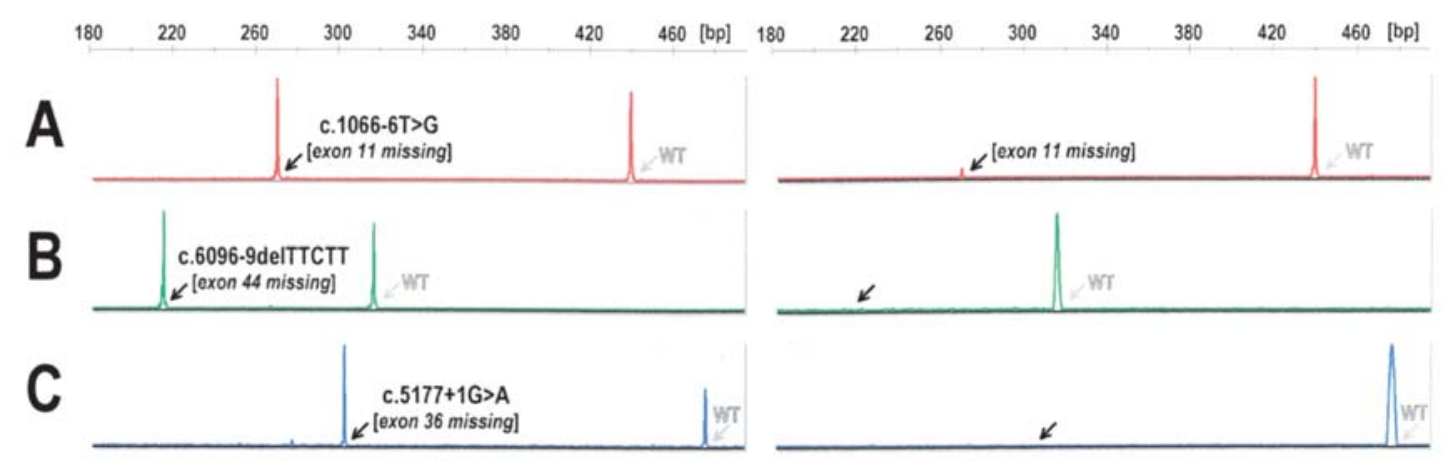

Figure 1. Quantitative analyses of RNA samples from breast cancer patients carrying splicing mutations in ATM and from unaffected control individuals. Patients heterozygous for truncating the mutations, c.1066-6T>G, c.6096-9delTTCTT and c.5177+1G>A and the corresponding controls are shown in A, B and $\mathrm{C}$, respectively. The black arrows indicate the position of shortened products and the grey arrows show wild-type transcripts.

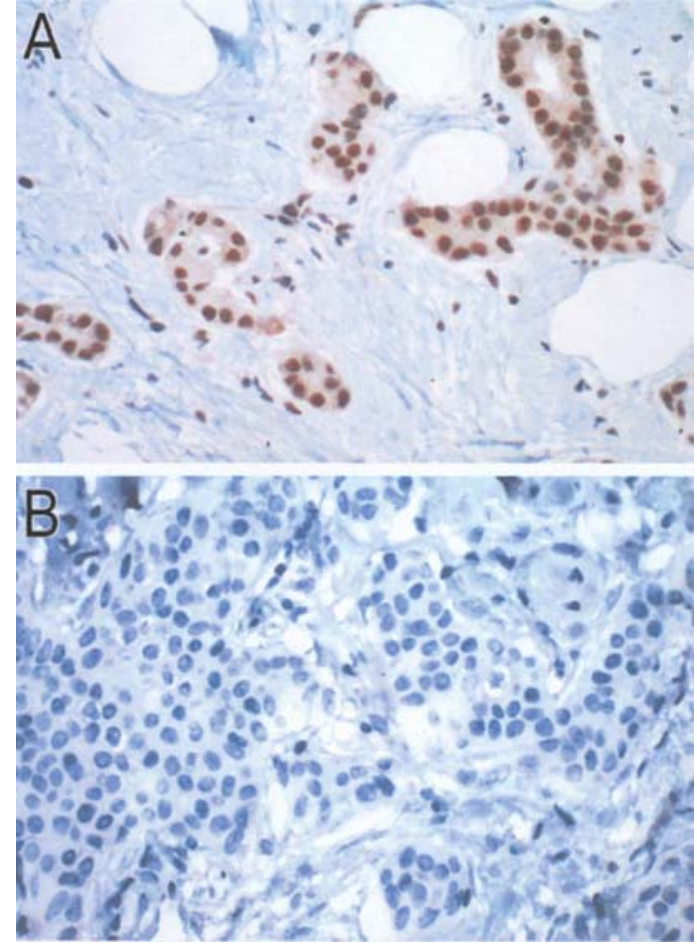

Figure 2. An immunohistochemical analysis of the ATM protein. (A) Breast tumor from a control patient (with wild-type ATM). (B) Breast tumor from a patient heterozygous for c. $5932 \mathrm{G}>\mathrm{T}$.

that this novel truncating mutation belongs to pathological gene alterations. The mutation c.6096-9delTTCTT (IVS439del5), described in AT patients, causes the skipping of the adjacent exon 44 as a result of the disturbance of the polypyrimidine tract close to the $3^{\prime}$ splice site (16). The c.1066$6 \mathrm{~T}>\mathrm{G}$ (IVS10-6T $>\mathrm{G})$ splicing variant also affects the highly conserved polypyrimidine region and leads to incorrect splicing and loss of exon 11 . The substitution has previously been identified in a number of breast cancer patients, but only once in an AT patient in a homozygous state $(10,17)$. We found this $A T M$ sequence alteration twice among controls.

Bilateral breast cancer and a strong family history of cancer occurred in two patients with the c.5177+1G $>\mathrm{A}$ or c. $5932 \mathrm{G}>\mathrm{T}$ truncating mutations. Other patients carrying the c.6096-9delTTCTT alteration were diagnosed with breast cancer before the age of 40. Patient with the c.1066-6T>G mutation developed breast cancer at the age of 32 and two other members of the family were also affected with this malignancy (Table II). DNA samples for genotyping were available in only one affected person in each family.

To investigate the effect of the mutations intervening in splicing, we performed quantitative analyses of RNA samples obtained from breast cancer patients carrying the mutations in ATM and from unaffected healthy individuals (Fig. 1). The analysis, performed in triplicate, showed that the patient carrying the novel mutation c. $5177+1 \mathrm{G}>\mathrm{A}$ expressed $53.6 \%$ of the spliced transcript but lacked exon 36 on average. Similarly, the AT-causing mutation c.6096-9delTTCTT leads to the skipping of exon 44 in $47.2 \%$ of the transcripts. No transcripts lacking exon 36 or 44 were observed in the controls. Three individuals (one patient and two controls) heterozygous for the mutation c.1066-6T $>\mathrm{G}$ displayed loss of exon 11 in $47-57 \%$ of $A T M$ transcripts. However, a small proportion (6-15\%) of incorrect splicing of exon 11 was also detected in the control blood samples without any alteration of this gene as well as in cancerous and adjacent noncancerous tissue samples obtained after surgical excision from c.1066-6T>G-negative patients with breast cancer.

The paraffin-embedded tumor samples were obtained from 3 ATM heterozygotes. Tumor tissue was not available in the patient carrying the c. $5177+1 \mathrm{G}>\mathrm{A}$ mutation. In one carrier, heterozygous for the c.1066-6T $>$ G mutation, DNA was isolated from the metastasis whereas in the other two patients from the primary tumors. The ATM mutations identified in peripheral blood were confirmed in each of the tumor samples. For LOH analysis, three microsatellite markers located within the ATM region were examined. However, none of the tumors from the heterozygous mutation carriers displayed $\mathrm{LOH}$ at this locus. Accordingly, it seems that the loss of the wild-type $A T M$ allele is not a common event in breast tumorigenesis. An alternative to gene inactivation includes promoter hypermethylation. However, our analyses did not detect any hypermethylation of the ATM promoter in any of the DNA samples from the tumor tissue. Nevertheless, immunohistochemistry, carried out with an antibody specific to the C-terminus of the protein, did not detect an ATM protein in any of the examined tumors. In a parallel analysis, breast carcinomas from patients without the ATM mutation expressed a high level of the ATM protein (Fig. 2). 


\section{Discussion}

In our study, pathogenic mutations in $A T M$ were detected in $3(1.9 \%)$ out of 161 high-risk breast cancer patients not related to $B R C A 1 / 2$, whereas no mutation was identified in the 183 controls. The incidence of truncating mutations predominant in AT was comparable to that ascertained in the UK (9/443, $2.0 \%)(18)$ and Austria (4/270, 1.5\%) (19).

The novel splicing mutation c. $5177+1 \mathrm{G}>\mathrm{A}$ affects the 5 ' splice site of intron 36 and results in the skipping of the adjacent exon and the premature termination of translation. A quantitative analysis showed that the shortened transcript with the loss of exon 36 represented $\sim 50 \%$ of the transcribed ATM mRNA in a heterozygous carrier of this mutation. No shortened transcripts were identified in the controls (Fig. 1C). Similar results of RNA analysis were obtained in a carrier of the splicing mutation c.6096-9delTTCTT that was confirmed to cause AT. Presented data indicate that the c.5177+1G $>$ A mutation can be predicted to cause AT.

We detected the splicing variant c.1066-6T $>\mathrm{G}$ once among the affected individuals $(1 / 161,0.6 \%)$ and twice among the controls $(2 / 183,1.1 \%)$. In the study of Szabo et al (20), similar frequencies of the c.1066-6T $>\mathrm{G}$ mutation were found in a group of breast cancer families from diverse geographical regions obtained from five centers $(8 / 961,0.8 \%)$ and in a group of control individuals $(4 / 543,0.7 \%)$. Eventually, neither did Bernstein et al find any association between c.1066-6T $>\mathrm{G}$ and breast cancer (21). In our study, incorrect splicing and loss of a small proportion of exon $11(\sim 10 \%)$ was also detected in the control individuals without the c.1066$6 \mathrm{~T}>\mathrm{G}$ mutation in the lymphocytes and breast tissue (Fig. 1A). Presented results suggest that the variant c.1066-6T $>$ G does not confer an elevated breast cancer risk. On the other hand, individuals heterozygous for the c.1066-6T $>\mathrm{G}$ variant displayed loss of exon 11 in $47-57 \%$ of ATM transcripts. There is also a discrepancy in the pathogenicity of the c.1066-6T >G variant with respect to AT. Despite the high population frequency, this variant has been identified in only one patient with AT who was homozygous for this gene alteration. However, this patient exhibited all the typical symptoms of classical AT. A quantitative analysis, performed in the lymphoblastoid cell line established from this patient, detected the loss of exon 11 in 93\% of ATM transcripts (10).

Cells from obligate AT heterozygotes display an increased chromosomal instability and have been shown to exhibit elevated radiosensitivity, which suggests that haploinsufficiency at the ATM locus may promote tumorigenesis $(22,23)$. On the contrary, a high frequency $(\sim 40 \%)$ of allelic losses at the ATM region in sporadic breast tumors supports the classic Knudson's two-hit hypothesis (24). Nevertheless, the process of inactivation of the retained allele remains poorly characterized. Immunohistochemistry proved the loss of expression of the ATM protein in all accessible tumor samples from the heterozygous mutation carriers, including the sample heterozygous for c.1066-6T>G mutation. To analyze the process of gene inactivation more precisely, we examined tumor samples for LOH at the ATM locus and for methylation of the $\mathrm{CpG}$ islands of the ATM promoter. However, LOH analyses did not reveal any allelic losses and the methylation of cytosine residues located within the $\mathrm{CpG}$ islands of the ATM promoter was not detected in any of the tumor samples.

To sum up, our results suggest that truncating mutations in ATM that occur in AT contribute, in heterozygous carriers, to breast cancer development. These results correspond to initial epidemiological studies in AT families. With respect to the occurrence in population, the splicing variant c.1066-6T>G was not associated with breast cancer. The absence of the ATM protein in the tumor samples of heterozygous mutation carriers suggests that a complete loss of this protein may be required for tumorigenesis. However, the precise mechanism of the second allele inactivation remains obscure.

\section{Acknowledgements}

This work was supported by the Internal Grant Agency of the Ministry of Health of the Czech Republic, Grant No. NR 9051-3 and the Research Project of the Ministry of Education MSM 0021620808.

\section{References}

1. Nathanson KL, Wooster R and Weber BL: Breast cancer genetics: what we know and what we need. Nat Med 7: 552-556, 2001.

2. Prokopcova J, Kleibl Z, Banwell CM and Pohlreich P: The role of ATM in breast cancer development. Breast Cancer Res Treat 104: 121-128, 2006

3. Bakkenist CJ and Kastan MB: DNA damage activates ATM through intermolecular autophosphorylation and dimer dissociation. Nature 421: 499-506, 2003.

4. Swift M, Morrell D, Cromartie E, Chamberlin AR, Skolnick MH and Bishop DT: The incidence and gene frequency of ataxiatelangiectasia in the United States. Am J Hum Genet 39: 573-583, 1986.

5. McKinnon PJ: ATM and ataxia-telangiectasia. EMBO Rep 5: 772-776, 2004.

6. Swift M, Morrell D, Massey RB and Chase CL: Incidence of cancer in 161 families affected by ataxia-telangiectasia. N Engl J Med 325: 1831-1836, 1991 .

7. Olsen JH, Hahnemann JM, Borresen-Dale AL, Brondum-Nielsen K, Hammarstrom L, Kleinerman R, Kaariainen H, Lonnqvist T, Sankila R, Seersholm N, Tretli S, Yuen J, Boice JD Jr and Tucker M: Cancer in patients with ataxia-telangiectasia and in their relatives in the Nordic countries. J Natl Cancer Inst 93: 121-127, 2001.

8. FitzGerald MG, Bean JM, Hegde SR, Unsal H, MacDonald DJ, Harkin DP, Finkelstein DM, Isselbacher KJ and Haber DA: Heterozygous ATM mutations do not contribute to early onset of breast cancer. Nat Genet 15: 307-310, 1997.

9. Ramsay J, Birrell $\mathrm{G}$ and Lavin M: Testing for mutations of the ataxia-telangiectasia gene in radiosensitive breast cancer patients. Radiother Oncol 47: 125-128, 1998

10. Dork T, Bendix R, Bremer M, Rades D, Klopper K, Nicke M, Skawran B, Hector A, Yamini P, Steinmann D, Weise S, Stuhrmann M and Karstens JH: Spectrum of ATM gene mutations in a hospital-based series of unselected breast cancer patients. Cancer Res 61: 7608-7615, 2001.

11. Renwick A, Thompson D, Seal S, Kelly P, Chagtai T, Ahmed M, North B, Jayatilake H, Barfoot R, Spanova K, McGuffog L, Evans DG, Eccles D, Easton DF, Stratton MR and Rahman N: ATM mutations that cause ataxia-telangiectasia are breast cancer susceptibility alleles. Nat Genet 38: 873-875, 2006.

12. Pohlreich P, Zikan M, Stribrna J, Kleibl Z, Janatova M, Kotlas J, Zidovska J, Novotny J, Petruzelka L, Szabo C and Matous B: High proportion of recurrent germline mutations in the BRCA1 gene in breast and ovarian cancer patients from the Prague area. Breast Cancer Res 7: R728-R736, 2005.

13. Chomczynski P and Sacchi N: Single-step method of RNA isolation by acid guanidinium thiocyanate-phenol-chloroform extraction. Anal Biochem 162: 156-159, 1987.

14. Telatar M, Teraoka S, Wang Z, Chun HH, Liang T, Castellvi-Bel S, Udar N, Borresen-Dale AL, Chessa L, Bernatowska-Matuszkiewicz E, Porras O, Watanabe M, Junker A, Concannon P and Gatti RA: Ataxia-telangiectasia: identification and detection of foundereffect mutations in the ATM gene in ethnic populations. Am J Hum Genet 62: 86-97, 1998. 
15. Den Dunnen JT and Paalman MH: Standardizing mutation nomenclature: why bother? Hum Mutat 22: 181-182, 2003.

16. Sandoval N, Platzer M, Rosenthal A, Dork T, Bendix R, Skawran B, Stuhrmann M, Wegner RD, Sperling K, Banin S, Shiloh Y, Baumer A, Bernthaler U, Sennefelder H, Brohm M, Weber BH and Schindler D: Characterization of ATM gene mutations in 66 ataxia telangiectasia families. Hum Mol Genet 8: 69-79, 1999.

17. Broeks A, Urbanus JH, de Knijff P, Devilee P, Nicke M, Klopper K, Dork T, Floore AN and van't Veer LJ: IVS10-6T>G, an ancient ATM germline mutation linked with breast cancer. Hum Mutat 21: 521-528, 2003.

18. Renwick A, Thompson D, Seal S, Kelly P, Chagtai T, Ahmed M, North B, Jayatilake H, Barfoot R, Spanova K, McGuffog L, Evans DG, Eccles D, Easton DF, Stratton MR and Rahman N: ATM mutations that cause ataxia-telangiectasia are breast cancer susceptibility alleles. Nat Genet 38: 873-875, 2006.

19. Thorstenson YR, Roxas A, Kroiss R, Jenkins MA, Yu KM, Bachrich T, Muhr D, Wayne TL, Chu G, Davis RW, Wagner TM and Oefner PJ: Contributions of ATM mutations to familial breast and ovarian cancer. Cancer Res 63: 3325-3333, 2003.

20. Szabo CI, Schutte M, Broeks A, Houwing-Duistermaat JJ, Thorstenson YR, Durocher F, Oldenburg RA, Wasielewski M, Odefrey F, Thompson D, Floore AN, Kraan J, Klijn JG, van den Ouweland AM, Wagner TM, Devilee P, Simard J, van't Veer LJ, Goldgar DE and Meijers-Heijboer H: Are ATM mutations $7271 \mathrm{~T} \rightarrow \mathrm{G}$ and IVS10-6T $\rightarrow \mathrm{G}$ really high-risk breast cancer-susceptibility alleles? Cancer Res 64: 840-843, 2004.
21. Bernstein JL, Teraoka S, Southey MC, Jenkins MA, Andrulis IL, Knight JA, John EM, Lapinski R, Wolitzer AL, Whittemore AS, West D, Seminara D, Olson ER, Spurdle AB, Chenevix-Trench G, Giles GG, Hopper JL and Concannon P: Population-based estimates of breast cancer risks associated with ATM gene variants c.7271T $>\mathrm{G}$ and c.1066-6T $>\mathrm{G}$ (IVS10-6T $>\mathrm{G}$ ) from the Breast Cancer Family Registry. Hum Mutat 27: 1122-1128, 2006.

22. Bay JO, Uhrhammer N, Pernin D, Presneau N, Tchirkov A, Vuillaume M, Laplace V, Grancho M, Verrelle P, Hall J and Bignon YJ: High incidence of cancer in a family segregating a mutation of the ATM gene: possible role of ATM heterozygosity in cancer. Hum Mutat 14: 485-492, 1999.

23. Lu S, Shen K, Wang Y, Santner SJ, Chen J, Brooks SC and Wang YA: Atm-haploinsufficiency enhances susceptibility to carcinogen-induced mammary tumors. Carcinogenesis 27: 848-855, 2006.

24. Rio PG, Pernin D, Bay JO, Albuisson E, Kwiatkowski F, De Latour M, Bernard-Gallon DJ and Bignon YJ: Loss of heterozygosity of BRCA1, BRCA2 and ATM genes in sporadic invasive ductal breast carcinoma. Int J Oncol 13: 849-853, 1998. 